employment of trained intelligence. The report takes the view that university students are too prone to ignore all avenues to worthwhile occupations other than the beaten paths of teaching, medicine, engineering, law, civil service, the church and set courses in industry and commerce. "Arts graduates, especially, rarely think of any possible occupation other than teaching". Such considerations point to the need for more recourse to vocational guidance. A firstyear course on careers, available for all students, was advocated in an address by Prof. J. H. Jones of the University of Leeds. It should aim at "the development of some conception of citizenship and social responsibility" and should be given, not by an appointments officer but by a number of persons experienced in their profession and in the life and purpose of a university. It should be voluntary, but time should be allowed from existing first-year courses to enable students in all faculties to attend. The Congress recorded its approval of the introduction of such orientation courses coupled with a recommendation of vocational guidance by 'careers masters' in schools and appointments boards in universities, mutually co-operating.
The question of limitation of entry into universities has an obvious bearing on graduate employment. This prickly subject is touched on in the report somewhat gingerly. Fairly general agreement was reached in discussions in the Commerce and Industry section that universities ought to select from among can. didates for admission only those capable of a dis. tinctively university type of education, "an education in which the student is not so much taught as provided with the tools for the acquisition of knowledge and technique", others being referred to suitable institutions providing higher education of a technical character. Presumably such a selection would be made after a brief probationary period of membership in the university. The report recognizes that any recommendation from a student body that there should be any limitation of educational opportunities might be open to misconstruction and abuse, and suggests, therefore, that the whole matter should be inquired into further by a thoroughly competent commission. The matter is certainly one of enormous importance, but it is difficult to imagine the desired reform being effected without infringing the autonomy of the universities.

\title{
Engineering Progress in the Navy
}

$\mathrm{I}^{\mathrm{N}}$ taking office, for a second term, as president of the North-East Coast Institution of Engineers and Shipbuilders, Prof. C. J. Hawkes delivered an address in which he reviewed some recent history of the engineering branch of the Royal Navy, established by Orders in Council just a hundred years ago. He referred in particular to the period of his own service, dating from 1900 , when great difficulties were being encountered with large water-tube boilers of the Belleville type. Smalltube Thornycroft boilers had given good results in H.M.S. Speedy in 1893. The decision in 1894 to install Belleville boilers in the 25,000 h.p. cruisers Powerful and Terrible was a momentous one and raised a storm of protest. The trials were satisfactory and demonstrated the weight-saving advantages, but later performance was disappointing, breakdowns were frequent and leakage was excessive, thus giving point and momentum to the attacks in Parliament and Press. The committee set up to investigate, however, confirmed the advantages and greater suitability of the water-tube as compared with the cylindrical boiler for use in the Navy. Improved methods of construction and the installation of special machinery in the dockyard enabled the Belleville boilers to give good service, but owing to inherent defects, including the long water and steam course of about $170 \mathrm{ft}$., some irregularity in water circulation and the deformation of tubes by local heating, it ultimately gave place to more modern designs.

In 1904, oil fuel as a supplement to coal was sanctioned, and seven years later it was decided that all new cruisers and battleships should be designed to burn oil only. Although this was a change of great national importance, it aroused none of the violent passions associated with the introduction of the large-tube water-tube boiler. From the engineer- ing point of view and that of the ship as a fighting unit, oil firing has several important advantages over hand-fired coal for steam raising. As native sources of supply are as yet quite inadequate to meet the needs of the Navy even in time of peace, the position is a difficult one, but so necessary is it that the Admiralty has decided to continue its use for steam raising in the Fleet. The production of oil fuel from coal is therefore being encouraged.

Up to 1900 all warships were propelled by reciprocating steam engines; the T.B.D. Viper was the first to have turbines. There were early difficulties in operating turbines at cruising speed and at full speed, but these were so far overcome that in 1905 it was decided that all future warships be fitted with turbine machinery and, in that year, the Dreadnought, the first turbine-driven battleship, was laid down. At first turbines were direct-coupled to propeller shafts, but from 1911 gearing was used, resulting in increased propulsive efficiency and reduced fuel consumption per shaft horse-power. The lubrication of multiple-thrust blocks was a constant difficulty and the author quotes a case in which, at a certain speed, the flow was reversed and oil from the thrust-block wells overflowed from the oil boxes situated 10-12 feet above the shaft. A system of forced lubrication was thereupon devised and worked without trouble, but the real solution came with the invention of the Michell thrust-block, which alone has made present-day shaft loads practicable.

Prof. Hawkes gave figures to show the saving of weight and space which has resulted from these and other improvements, the more marked as they are accompanied by greater reliability and durability. Further advances may be looked for, but it must be borne in mind that in naval design there are limita. tions which do not apply to land practice. 